\title{
The effectiveness of the Think Pair Share (TPS) method on explanatory text writing skills in terms of learning styles Yolani Erawatia ${ }^{\mathrm{a}}$, Syahrul Ramadhan ${ }^{\text {b2 }}$
}

Indonesian Language and Literature Program, Faculty of Language and Arts, Padang State University West Sumatra ${ }^{\mathrm{a}, \mathrm{b}}$ yolanierawati@gmail.com ${ }^{\mathrm{I}}$, syahrulramadhan.532@,gmail.com ${ }^{2}$

\begin{tabular}{ll} 
Article's information \\
\hline History: & \\
Submitted: & I8 Mei 202I \\
Revised: & 2I September 202I \\
Published: & 30 Oktober 202I
\end{tabular}

Kata kunci:

Think pair share

Gaya belajar

Keterampilan menulis

Teks eksplanasi

\section{ABSTRAK}

Penelitian ini bertujuan untuk meninjau efektivitas metode think pair share terhadap keterampilan menulis teks eksplanasi ditinjau dari gaya belajar. Jenis penelitian ini adalah kuantitatif dengan metode eksperimen faktorial $2 \times 2$. Populasi dalam penelitian ini adalah seluruh siswa kelas VIII SMP Negeri I Kinali. Data penelitian dikumpulkan menggunakan angket dan tes unjuk kerja. Berdasarkan hasil analisis data, dapat disimpulkan (I) keterampilan menulis teks eksplanasi siswa yang belajar dengan metode think pair share lebih tinggi daripada siswa yang yang belajar dengan metode konvensional, (2) keterampilan menulis teks eksplanasi siswa yang memiliki gaya belajar tinggi yang belajar dengan metode think pair share lebih tinggi daripada siswa yang yang belajar dengan metode konvensional, (3) keterampilan menulis teks eksplanasi siswa yang memiliki gaya belajar rendah yang yang belajar dengan metode think pair share lebih tinggi daripada siswa yang yang belajar dengan metode konvensional, dan (4) terdapat interaksi antara metode think pair share dan gaya belajar dalam mempengaruhi keterampilan menulis teks eksplanasi.

\section{Key word: \\ Think pair share \\ Learning styles \\ Writing skills \\ Explanatory text.}

\section{ABSTRACT}

This study aims to review the effectiveness of the think pair share method on explanatory text writing skills in terms of learning styles. This type of research is quantitative with the $2 \times 2$ factorial experimental method. The population in this study were eighth grade students of SMP Negeri I Kinali. Research data was collected using a questionnaire and performance test. Based on the results of data analysis, it can be concluded that (I) the explanatory text writing skills of students who study using the think pair share method are higher than students who study using conventional methods, (2) the explanatory text writing skills of students who have high learning styles who study with the think pair share method are higher than students who learn by conventional methods, (3) the explanatory text writing skills of students who have low learning styles who study with the think pair share method are higher than students who learn by conventional methods, and (4) there is an interaction between the think pair share method and learning styles in influencing the skills of writing explanatory texts.

Copyright (C) 2018 Universitas Ahmad Dahlan. All Right Reserved

\section{Introduction}

Implementation of the 2013 curriculum in Indonesian language learning must involve all components of language skills, one of which is writing skills. Writing skill is defined as the ability to express one's thoughts into written language by using sentences that are clearly and completely composed, rendering it comprehensibleto the reader (Byrne in Mardiyah, 2016). Writing is the most effective method of communication to improve students' abilities so that they would be able to express ideas in writing based on their knowledge (Mulyani \& Syahrul, 2019; Simpson, 2017).

In Indonesia, students' writing skills are still relatively low. The low students' writing skills also occur in the explanatory text writing skills. Fitri, et al. (2018) in his research stated that many students' scores in the skill of writing explanatory texts did not reach the KBM (Minimum Learning Completeness). Based on the facts found in several studies, it is stated that students have difficulty in expressing their thoughts and ideas, or in writing structured texts (Gusnita, et al., 2018; Rasyad, 2017; Saleh, 2016). This is because students do not understand the concept of writing an explanatory text based on the correct structure and systematics (Apriyani, 2019; Meladina, 2019; Shinta, et al., 2017). Another factor is because the presentation of materials, techniques, and the use of methods and models in learning do not vary, so students in the learning process feel bored and sleepy (Salvera, 2017). 
The right method can make students more enthusiastic in receiving subject matter and can improve student learning outcomes. One method that can be used in explanatory text learning is the Think Pair Share (TPS) method. The think pair share method is part of a cooperative learning model that gives students time to think, respond and help each other. The application of this method has several advantages, namely providing thinking time to improve the quality of student responses, making students more active in thinking about concepts in the subject, making students understand more about the concepts of lesson topics during discussion, and that students would be able to learn from their peers (Shoimin, 2016, p. 2II-2I2).

The think pair share method is very effective in learning and has a great influence in improving student learning outcomes (Istigfara \& Afnita, 2020; Rahmawati, 2017; Arki, et al., 2017). Susanti, et al. (2018) in their research states that the think pair share method has an influence in improving students' news text writing skills. This is evidenced by the increase in the average score of students' news text writing skills after the application of the think pair share method from an average of 62,39 (sufficient qualification) to an average of 84,83 (good qualification). In addition, Wasillah, et al. (2016) in their research also stated that this method had an effect on improving drama script writing skills as evidenced by tcount $>$ table $(9.32>1.67)$.

In addition to learning methods, learning styles also affect writing skills and student learning outcomes. Jamulia's (2018) research states that the way a person receives and processes information when learning affects their learning outcomes. In understanding the lesson, each student has different characteristics of brain abilities (Widayanti, 2013). Students also have different learning styles in receiving information (Churngchow, et al., 2020). According to Brown (in Wiedarti, 20I8, p. I), learning style is the manner in which someone receives and processes information.

Based on the sensory approach (learning modalities), learning styles are divided into visual, audio, and kinesthetic learning styles. The first, visual learning style, is a learning style that relies on the sense of sight in the learning process (Chania, et al., 2016). The second, audio learning style, uses the sense of hearing to conduct learning activities (Papilaya \& Huliselan, 2016). Third, the kinesthetic learning style is a way of learning that is done by doing experience, movement, and touch to obtain information (Subini, 20II, p. 2I).

A person's learning style is influenced by physical, emotional, sociological, and environmental factors. Ghufron \& Risnawita (2013, p. I38) suggest that there are several benefits related to the need for teachers' understanding of student learning styles in learning, namely helping students to have a positive outlook; make learning more open; facilitate the learning styles of each student; can find out the interests and characteristics of students; make learning more interesting so that students are active in learning; and use learning methods that are appropriate to students' learning styles.

The problem in this research is formulated into four formulations. First: are the explanatory text writing skills of students who study with the think pair share method higher than those of students who study conventionally? Second: are the explanatory text writing skills of students with high learning styles with the think pair share method better than those with high learning styles but conventional? Third: are the explanatory text writing skills of students with low learning styles with the think pair share method higher than students with low learning styles who study conventionally? Fourth: is there an interaction between the think pair share method and students' learning styles on the skill of writing explanatory text?

The aims of this study are as follows: First, to describe the students' explanatory text writing skills who study using the think pair share method and study using the conventional method. Second, describe the explanatory text writing skills of students who have high learning styles who study using the think pair share method and students with high learning styles who study conventionally. Third, describe the skills of writing explanatory texts for students who have low learning styles who study using the think pair share method and students who have low learning styles who study using conventional methods. Fourth, describe the interaction between the think pair share method and students' learning styles in influencing explanatory text writing skills.

Theoretically, the results of this study are expected to (I) contribute ideas in improving the quality of Indonesian language learning, especially regarding explanatory text material using the think pair share method and other methods that are adapted to students' learning styles; (2) as a basis and reference for further research related to the skill of writing explanatory texts, think pair share methods and learning styles, as well as material for further studies.

\section{Method}

This research was conducted using a quasi-experimental design or a quasi-experimental design with a $2 \times 2$ factorial research design. The research was conducted at SMP Negeri I Kinali, West Pasaman Regency in the even semester of the 2020-202I school year. The research population is I35 students of class VIII SMP Negeri I 
Kinali who were spread between 5 classrooms. The sample used in this study was class VIII3 (experimental class) and VIII4 (control class) with 3I students each, obtained by purposive sampling technique. The experimental class uses the think pair share method and the control class uses the conventional method.

The variables used in this study are divided into three, namely the think pair share method as the independent variable, learning style as a moderator variable, and explanatory text writing skills as the dependent variable. The research data were derived from (I) learning style questionnaire scores; (2) explanatory text writing skill test scores using the think pair share method and conventional methods; (3) the test scores of students' explanatory text writing skills who have high learning styles and low learning styles using the think pair share method; (4) Explanatory text writing skill test scores of students who have high learning styles and low learning styles using conventional methods.

The instrument for collecting data in this study consisted of non-test and test. Non-test instrument in the form of a questionnaire used to collect data on student learning styles. The learning style questionnaire was compiled based on 4 indicators, namely how to absorb and process information (learning modalities); personality; social interaction; and environmental interactions. The questionnaire statement has 5 alternative answers, namely: always, often, sometimes, rarely, and never. Before being distributed to the research sample, the questionnaire was first tested to determine the level of validity and reliability of the test. Testing the validity of the learning style questionnaire was carried out using the product moment correlation analysis formula, and reliability testing was carried out using the alpha formula. Meanwhile, the test instrument is in the form of a performance test which is used to measure students' explanatory text writing skills. The test is first consulted with Indonesian language teachers and experts who understand the evaluation of learning before it is given to students.

Test requirements analysis was carried out with normality test and homogeneity test. The normality test is carried out through the Lilliefors test with the following steps: (I) compiling the data obtained from the smallest data to the largest data, and making the data into standard numbers, (2) each standard number is distributed with an $\mathrm{F}$ distribution, (3) determining $\mathrm{S}\left(\mathrm{zi}_{\mathrm{i}}\right)$ by calculating the proportion divided by the number of (n) samples, (4) calculating the $\mathrm{F}\left(\mathrm{zi}_{\mathrm{i}}\right)-\mathrm{S}\left(\mathrm{zi}_{\mathrm{i}}\right)$ difference and determining the absolute value, (5) obtaining the largest price between the absolute price difference, which is then called $\mathrm{L}_{\circ},(6)$ comparing $\mathrm{L}_{\circ}$ with L tabel to accept or reject the hypothesis. The homogeneity test was carried out using the formula for the comparison of the largest to the smallest variance by searching for each variant of the data group, then the $\mathrm{F}_{\text {count }}$ price can be calculated.

Research hypotheses I, 2, and 3, were tested using the two-mean test or t-test. The stages in conducting the test (I) determining $\mathrm{HO}$ and $\mathrm{HI}$, (determining the level of significance, (3) performing a variance test, (4) calculating the value of $t$ and $\mathrm{df}$, (5) comparing the value of tcoun with trable, (6) concluding the hypothesis. Furthermore, Hypothesis 4 was tested using the two-way ANOVA test or the f-test with the following stages: (I) calculating the total number of squares, (2) calculating the number of squares between groups A and B, (3) calculating the number of inner squares, (4) determining the degrees of freedom, (5) determining the number of squares, (6) determining $F_{\text {count }}$ and comparing it with $\mathrm{F}_{\text {table, }}(7)$ concluding the hypothesis.

\section{Results and Discussion}

This section is broken down into four main points of study, namely (I) the explanatory text writing skills of students who study using the think pair share method and the conventional method, (2) explanatory text writing skills of students who have a high learning style who study using the think pair share method and other methods. conventional methods, (3) students' explanatory text writing skills who have low learning styles who study using the think pair share method and conventional methods, (4) the interaction between think pair share learning methods and learning styles in influencing the explanatory text writing skills.

I. Explanatory Text Writing Skills for Students who StudyusingThink pair share Methods and Conventional Methods

The explanatory text writing skills of students who studied with the think pair share method were higher than those of students who studied with the conventional method. The data can be seen in the following table:

Table I. Explanatory Text Writing Skills for Experiment Class and Control Class Students

\begin{tabular}{|c|c|c|c|c|c|}
\hline $\mathrm{Cla}$ & & & I & & \\
\hline ss & $\begin{array}{l}\text { ighest } \\
\text { Score }\end{array}$ & $\begin{array}{l}\text { owest } \\
\text { Score }\end{array}$ & & & $S$ \\
\hline Ex & & & 6 & & \\
\hline periment & 6 & 8 & I.74 & I & .22 \\
\hline $\begin{array}{ll} & \text { Co } \\
\text { ntrol } & \end{array}$ & 0 & 3 & 4.55 & I & .34 \\
\hline
\end{tabular}


Based on the table above, the average value of explanatory text writing skills obtained by students in the experimental class is 81.74 , while the average score obtained by students in the control class is 74.55 . The results of the normality test of the experimental class and control class data are normal. In the experimental class LO $<\mathrm{Lt}$ $(0.009<0.159)$ and similarly in the control class LO $<\operatorname{Lt}(0.068<0.159)$ with each $N=3$ I. The homogeneity test of variance was carried out in the experimental class with $\mathrm{N}=3 \mathrm{I}, \mathrm{S}^{2}=52 . \mathrm{I} 3$ and the control class with $\mathrm{N}=$ $3 \mathrm{I}, \mathrm{S}^{2}=69.56$. The value of $\mathrm{F}_{\mathrm{t}}$ in the experimental and control classes with $\mathrm{dk}=30$ is $\mathrm{I} .84$ at a significance level of 0.05 , while $\mathrm{F}_{\mathrm{h}}$ is 0.75 . Thus $\mathrm{F}_{\mathrm{h}}<\mathrm{F}_{\mathrm{t}}(0.75<\mathrm{I} .84)$, meaning that both classes have homogeneous variance.

After testing the requirements of the analysis with the normality test and homogeneity test, then the hypothesis test was carried out. The experimental class had $\mathrm{N}=3 \mathrm{I}, \bar{x}=8 \mathrm{I} .74, \mathrm{~S}^{2}=52 . \mathrm{I} 3$ and the control class had $\mathrm{N}=3 \mathrm{I}, \bar{x}=74.55, \mathrm{~S}^{2}=69.56$. Calculations using the $\mathrm{t}$ test produced $\mathrm{t}_{\text {count }}=3.68$ at the significance level of 0.05 and $d k=(n I+n 2)-2$, resulting in $t_{t a b l e}=1.67$. Since $t_{\text {count }}>t_{t a b l e}$. Hois rejectedand $H_{1}$ is accepted. It can be concluded that the explanatory text writing skills of students who study using the think pair share method are higher than the explanatory text writing skills of students who study using conventional methods.

The explanatory text writing skill of students who study using the think pair share method was higher than the explanatory text writing skill of students who study using the conventional method. This is because students were afforded the time to think, respond and help each other in learning using the think pair share method (Huda, 2015, p. 206). The think pair share method enables students to develop themselves and apply the knowledge that has been obtained, making them more active in expressing their thoughts. Students can also discuss, share opinions, and accept each other's opinions between groups. Meanwhile, in conventional methods, the teacher's role tends to be more dominant than students (Sanjaya, 2016, p. 259), so that students become inactive and do not have much time to do independent activities to understand the subject matter. They also have a low level of material mastery.

\section{Explanatory Text Writing Skills of Students with High Learning Styles who Learn with Think pair share Method and Conventional Method}

The explanatory text writing skills of students who have high learning styles who study using the think pair share method are higher than the explanatory text writing skills of students who have high learning styles who study using conventional methods. The data can be seen in the following table.

Table 2. Explanatory Text Writing Skills of Students who have high learning styles Experiment Class and Control

\begin{tabular}{cccccc}
\hline Class & $\begin{array}{c}\text { Highest } \\
\text { Score }\end{array}$ & $\begin{array}{c}\text { Lowest } \\
\text { Score }\end{array}$ & $\mathrm{X}$ & $\mathrm{N}$ & $\mathrm{S}$ \\
& 96 & $8 \mathrm{I}$ & 88.67 & 9 & $4.6 \mathrm{I}$ \\
Experiment & 90 & 70 & 80.67 & 9 & 7.47 \\
Control & & &
\end{tabular}

Based on the table above, the average score obtained by students in the experimental class was 88.67 , while students in the control class got an average score of 80.67. The average is obtained from the value of 9 students who have high learning styles in the experimental class and control class. Determination of groups of students who have a high learning style is done by taking $27 \%$ of the number of students in the experimental class and control class, 3 I students each.

The results of the normality test of the explanatory text writing skills of students who have high learning styles in the experimental class and control class are normal. In the experimental class $\mathrm{L}_{0}<\mathrm{L}_{\mathrm{t}}(-0.053<0.27 \mathrm{I})$, in the control class too $\mathrm{L}_{0}<\mathrm{L}_{\mathrm{t}}(\mathrm{O} . \mathrm{I}$ I $4<0.27 \mathrm{I})$ with each $\mathrm{N}=9$. The homogeneity test of variance was carried out in the experimental class with $\mathrm{N}=9, \mathrm{~S}^{2}=2 \mathrm{I} .25$ and control class with $\mathrm{N}=9, \mathrm{~S}^{2}=55.80$. The value of Fin the experimental and control classes with $\mathrm{dk}=8$ is 3.44 at the level of significance of 0.05 , whereas Fhis 0.38 . Therefore, $\mathrm{F}_{\mathrm{h}}<\mathrm{F}_{\mathrm{t}}(0.38<3.44)$, which means that both classes have homogeneous variance.

After testing the requirements of the analysis, the hypothesis test is carried out. The experimental class has $\mathrm{N}=9, \bar{x}=88.67, \mathrm{~S}^{2}=21.25$ and the control class has $\mathrm{N}=9, \bar{x}=80.67, \mathrm{~S}^{2}=55.80$. The results of calculations using the t-test obtained $t_{\text {count }}=2.80$ at the level of $\alpha=0,05$ and $\mathrm{dk}=(\mathrm{nI}+\mathrm{n} 2)-2$ yields in table $=1.74$. Since $t_{\text {count }}>t_{\text {table, }} H_{0}$ is rejected and $H_{\mathrm{I}}$ is accepted. It can be concluded that the explanatory text writing skills of students who have high learning styles who study using the think pair share method are higher than students who study using conventional methods.

Learning in the experimental class is carried out using the think pair share method which makes students think independently, more diligently in learning, and active in finding learning resources so that it is easier for these students to solve problems. Apriyanti \& Ayu (2020) in their research stated that the think pair share method increases class participation by encouraging high-level student responses. Thus, indirectly students who have a high learning style will find it easier to conclude and analyze the problems given. The use of the think pair share method 
and supported by high student learning styles will have an effect on improving students' explanatory text writing skills. In the control class, when learning students only listened and took notes on the material presented by the teacher. This resulted in them being less active and having limited abilities at low levels.

\section{Explanatory Text Writing Skills Students with Low Learning Styles who Study Using the Think Pair Share Method and Those with Conventional Method}

The explanatory text writing skills of students who have low learning styles who study using the think pair share method are better than the explanatory text writing skills of students who have low learning styles who study using conventional methods. The data can be seen in the following table.

Table 3. Explanatory Text Writing Skills Students who have high learning styles Experiment Class and Control

\begin{tabular}{cccccr}
\hline Class & $\begin{array}{c}\text { Highest } \\
\text { Score }\end{array}$ & $\begin{array}{c}\text { Lowest } \\
\text { Score }\end{array}$ & $\mathrm{X}$ & $\mathrm{N}$ & $\mathrm{S}$ \\
& 90 & 68 & 80,67 & 9 & 6,20 \\
Experiment & 82 & 53 & 70,22 & 9 & 8,93 \\
Control & &
\end{tabular}

Based on the table above, the average score obtained by students in the experimental class is 80.67 , while the average score obtained by students in the control class is 70.22. The average value is the value of 9 students who have low learning styles in the experimental class and control class. Determination of groups of students who have low learning styles is to take $27 \%$ of the number of students in the experimental class and control class, each of which is 3 I people.

The results of the normality test of the explanatory text writing skills of students who have low learning styles in the experimental class and control class are normal. In the experimental class $\mathrm{L}_{0}<\mathrm{L}_{\mathrm{t}}(0.075<0.27 \mathrm{I})$ and in the control class $\mathrm{L}_{0}<\mathrm{L}_{\mathrm{t}}(0.068<0.27 \mathrm{I})$ with each $\mathrm{N}=9$. The homogeneity test of variance was carried out in the experimental class with $\mathrm{N}=9, \mathrm{~S}^{2}=38.44$ and control class with $\mathrm{N}=9, \mathrm{~S}^{2}=79.74$. The value of $\mathrm{F}_{\mathrm{t}}$ in the experimental and control classes with $\mathrm{dk}=8$ is 3,44 at the significance level of 0.05 whereas $F_{h}$ is 0.48 . Therefore $\mathrm{F}_{\mathrm{h}}<\mathrm{F}_{\mathrm{t}}(0.48<3.44)$, which means that both classes have homogeneous variance.

Hypothesis testing was carried out using the $\mathrm{t}$ test formula. The experimental class has $\mathrm{N}=9, \bar{x}=80.67$, $\mathrm{S}^{2}=38.44$ and the control class has $\mathrm{N}=9, \bar{x}=70.22, \mathrm{~S}^{2}=79.74$. Hypothesis calculation results in tcount $=2,96$ at significance level 0.05 and $d k=(n I+n 2)-2$ yields trable $=1.74$. Since $t_{c o u n t}>t_{\text {table, }} H_{0}$ is rejected and $H_{\mathrm{I}}$ is accepted. It can be concluded that the explanatory text writing skills of students who have low learning styles who study using the think pair share method are higher than the explanatory text writing skills of students who have low learning styles who study using conventional method.

The application of the think pair share method in learning helps students who have low learning styles in writing explanatory texts. The think pair share method gives students time to think so that students can improve the quality of their responses, and they can better understand the subject matter during discussions (Shoimin, 2016, p. 2II-2I2). This is what can help students who have low learning styles in writing explanatory texts well. In contrast to the experimental class, students who have low learning styles in the control class have difficulty in writing explanatory texts. This is because their learning method is conventional. In its application, conventional methods make students as learning objects and passive recipients of information. Learning activities are generally carried out individually and theoretically, so students who have low learning styles are not interested in participating in learning and lack mastery of the material, resulting in low students' explanatory text writing skills.

4. Interaction between Think Pair Share Method and Learning Style on Explanatory Text Writing Skills

Learning style is the way a person receives and processes the information obtained (Brown in Wiedarti, 20I8, p. I). Student learning outcomes are influenced by student learning styles. Jamulia (2018) in his research states that student learning outcomes are influenced by the way the student receives and processes information when learning. That is, the higher the learning style of students, the better their learning outcomes.

Based on data analysis, there are differences in the average explanatory text writing skills of students in the experimental class and the control class. The number of students in each class is 18 people which are divided into 9 students with high learning styles and 9 students with low learning styles. The explanatory text writing skills of students who have high and low learning styles who study using the think pair share method have an average of 84.67 while the explanatory text writing skills of students who have high and low learning styles who study using conventional methods have an average of 75,44 . This means that the explanatory text writing skills of students who study with the think pair share method are higher than those who study using conventional method.

Students who have high and low learning styles who study with the think pair share method, N = I8, L。 $<\mathrm{Lt}_{\mathrm{t}}(0.013<0.200)$, which means that the skills of writing explanatory texts for students who have high and low learning styles who study using the think pair share method are normally distributed. For students who study 
with conventional methods, $\mathrm{N}=\mathrm{I} 8$, $\mathrm{L}_{\circ}<\mathrm{L}_{\mathrm{t}}(0.054<0.200)$, which means that students' explanatory text writing skills have high and low learning styles who study using conventional methods with a normal distribution.

Furthermore, the homogeneity test of variance was carried out on the data of students who have high and low learning styles who study using the think pair share method with $\mathrm{N}=\mathrm{I} 8, \mathrm{~S}^{2}=45.02$ and those who study using conventional methods with $\mathrm{N}=18, \mathrm{~S}^{2}=92.54$. The value of $\mathrm{F}_{\mathrm{t}}$ on students who have high and low learning styles who study with the think pair share method and conventional methods with $\mathrm{dkI}=\mathrm{I} 7$ and $\mathrm{dk} 2=\mathrm{I} 7$ is 2.27 at significance level of 0.05 , whereas $F_{h}$ is 0.49 . Therefore, $F_{h}<F_{t}(0,49<2,27)$, which means that the explanatory text writing skills of students who have high and low learning styles who study using the think pair share method and conventional method have homogeneous variances.

Hypothesis testing was carried out to determine the interaction between variables carried out by two-way ANOVA test or $\mathrm{f}$-test. Hypothesis testing produces $\mathrm{F}_{\text {count }}=0,295$ with $\mathrm{dbk}=\mathrm{I}, \mathrm{dbd}=32$, and $\mathrm{F}_{\text {table at significance }}$ level of $0.05=4.15$. Therefore $\mathrm{F}_{\text {count }}<\mathrm{F}_{\text {table }}(0.295<4.15)$, it can be concluded that there is an interaction between the think pair share method and learning style on explanatory text writing skill.

\section{Conclusion}

Based on the results and discussion, the following four points can be concluded. First, the explanatory text writing skills of students who study using the think pair share method are higher than those who study using conventional method. Second, the explanatory text writing skills of students who have high learning styles who study using the think pair share method are higher than those who have high learning styles who study using conventional method. Third, the explanatory text writing skills of students who have low learning styles who study using the think pair share method are higher than those who have low learning styles who study using conventional method. Fourth, there is an interaction between the think pair share method and learning styles in influencing explanatory text writing skill.

\section{Acknowledgment}

The author's gratitude goes to Prof. Dr. Syahrul R., M.Pd. who had guided the author in completing this research. The author also thanks the principal of SMP Negeri I Kinali who has given permission to conduct research, as well as the students who participated in this research.

\section{REFERENCES}

Apriyani, N. N. (2019). Pembelajaran Menulis Teks Eksplanasi Menggunakan Media Film Strips pada Siswa Kelas XI MAN 6 Tasikmalaya. Jurnal Diksatrasia, 3 (2), 60-74.

Apriyanti,. \& Ayu, M. (2020). Think Pair Share: Engaging Students in Speaking Activities in Classroom. Journal of English Language Teaching and Learning, I (I), I3-I9.

Chania, Y., Hafiz, M., \& Sasmita. (2016). Hubungan Gaya Belajar dengan Hasil Belajar Siswa pada Pembelajaran Biologi Kelas X SMAN 2 Sungai Tarab Kabupaten Tanah Datar. Journal of Sainstek, 8 (I), 77-84.

Churngchow, C., Rorbkorb, N., Petchurai, O., \& Tansakul, J. (2020). Appropriate Learning Management for Students with Different Learning Styles within a Multicultural Society at State-run Universities in Thailand. International Journal of Higher Education, 9 (2), 200-208.

Fitri, M. M., Syahrul. R. \& Afnita. (2018). Pengaruh Model Discovery Learning Berbantuan Media Gambar Berseriterhadap Keterampilan Menulis Teks Eksplanasi Siswa Kelas VIII SMP Negeri 25 Padang. Jurnal Pendidikan Bahasa dan Sastra Indonesia, I (7), I33-I4I.

Ghufron, M. N. \& Risnawita, R. (2013). Gaya Belajar Kajian Teorik. Jogjakarta: Pustaka Pelajar.

Gusnita, Y. Basri, I., \& Ratna, E. (2018). Pengaruh Teknik Copy the Master Terhadap Keterampilan Menulis Teks Eksplanasi. Jurnal Pendidikan Bahasa dan Sastra Indonesia, I (7), I75-I82.

Huda, M. (2015). Coopertive Learning. Yogyakarta: Pustaka Belajar.

Istigfara, T. \& Afnita. (2020). Model Pembelajaran Kooperatif Tipe Think Pair Share (TPS) dalam Pembelajaran Membaca Pemahaman Cerpen. Jurnal Pendidikan Bahasa dan Sastra Indonesia, 9 (I), I4-I8.

Jamulia, J. (20I8). Identifying Students Learning Style Preferences at IAIN Ternate. International Journal of Education, IO (2), I2I-I29.

Mardiyah. (2016). Keterampilan Menulis Bahasa Indonesia melalui Kemampuan Mengembangkan Struktur Paragraf. Jurnal Pendidikan dan Pembelajaran Dasat, 3 (2), I-22.

Meladina. (2019). Students Ability, Problems and Causes of Problem in Writing Explanation Text at The First Grade of SMAN I Batusangkar. Curricula: Journal of Teaching and Learning, 4 (I), 8-I9. 
Mulyani, R. \& Syahrul, R. (2019). Pengaruh Model Pembelajaran Kooperatif Tipe Think Talk Write (TTW) Berbantuan Media Audiovisual terhadap Keterampilan Menulis Teks Persuasi Siswa Kelas VIII SMP Negeri 8 Padang. Jurnal Pendidikan Bahasa dan Sastra Indonesia,8 (3), 374-382.

Papilaya, J. O. \& Huliselan, N. (2016). Identifikasi Gaya Belajar Mahasiswa. Jurnal Psikologi UNDIP, I5 (I), 5663.

Rahmawati, O. I. (2017). Think Pair Share: A Tecnique To Enhance Students Writing Skill. Jurnal Pendidikan Edutama,4 (I), 49-58.

Rasyad, S., Juwanda, \& Lestari, R. Y., (2017). Penerapan Metode Pembelajaran Mencari Pasangan dalam Pembelajaran Memproduksi Teks Eksplanasi Kompleks pada Siswa Kelas XI SMK Negeri I Lemahabang. Deiksis: Jurnal Pendidikan Bahasa dan Sastra Indonesia, 4 (I).

Saleh, M. (2016). Peningkatan Kemampuan Menulis Teks Eksplanasi Komplek melalui Model STAD pada Siswa SMA. Briliant: Jurnal Riset dan Konseptual, I (I).

Salvera, N. (2017). Meningkatkan Kemampuan Menulis Teks Eksplanasi dengan Menggunakan Media Gambar Berseri pada Siswa Kelas VII. Educatio: Jurnal Pendidikan Indonesia, 3 (2), 32-43.

Sanjaya, W. (2016). Strategi Pembelajaran berorientasi Standar Proses Pendidikan. Jakarta: Perdana Media.

Shinta, Y. (2017). Penerapan Model Pembelajaran Berdasarkan Masalah dan Media Video Animasi Peristiwa Sosial Bermuatan Pendidikan Multikultural untuk Meningkatkan Keterampilan Menyusun Teks Eksplanasi. Basindo: Jurnal Kajian Bahasa, Sastra Indonesia, dan Pembelajaran, I (2).

Shoimin, A. (2016). 68 Model Pembelajaran Inovatif dalam Kurikulum 2013. Yogyakarta: AR-Ruzz Media.

Simpson, J. (2017). Using Facebook in an EFL Business English Writing Class in a Thai University: Did It Improve Students Writing Skills? Education and Language International Conference Proceedings Center for International Language Development of Unissula, I3-28.

Subini, N. (20II). Rahasia Gaya Belajar Orang Besar. Jakarta: PT. Buku Kita.

Trianto. (2009). Mendesain Model Pembelajaran Inovatif dan Progresif konsep dan Implementasinya Pada Kurikulum Tingkat Satuan Pendidikan. Jakarta: Kencana Prenada Group.

Wasillah, T., Syahrul, R. \& Noveria, E. (2016). Pengaruh Model Pembelajaran Kooperatif Tipe Think Pair Share terhadap Keterampilan Menulis Naskah Drama Satu Babak Siswa Kelas VIII SMP Negeri 30 Padang. Jurnal Pendidikan Bahasa Dan Sastra Indonesia, 5 (I), 8-I6.

Widayanti, F. (2013). Pentingnya Mengetahui Gaya Belajar Siswa dalam Kegiatan Pembelajaran di Kelas. Jurnal Erudio, 2(I), 7-2I.

Wiedarti, P. (2018). Pentingnya Memahami Gaya Belajar. Jakarta: Direktorat Jenderal Pendidikan Dasar dan Menengah Kementerian Pendidikan dan Kebudayaan. 